\title{
STANDARDIZED TERMINOLOGY OF ADULT SPINE DEFORMITY FOR BRAZILIAN PORTUGUESE
}

\author{
TERMINOLOGIA PADRONIZADA DA DEFORMIDADE VERTEBRAL \\ DO ADULTO PARA O PORTUGUÊS DO BRASIL
}

\section{TERMINOLOGÍA ESTANDARIZADA DE LA DEFORMIDAD ESPINAL DEL ADULTO PARA EL PORTUGUÉS DE BRASIL}

Raphael de Rezende Pratali', Sergio Afonso Hennemann², Rodrigo Amaral ${ }^{3}$, luis Eduardo Carelli Teixeira da Silva4 4 ,

Marcio Oliveira Penna de Carvalho ${ }^{5}$, Murilo Tavares Daher ${ }^{6}$, Fernando Antonio Mendes Façanha Filho ${ }^{7}$, Asdrubal Falavigna 8 ,

Eduardo Gil França Gomes ${ }^{9}$, Carlos Henrioue Maçaneiro ${ }^{10}$, Augustin Malzac ${ }^{11}$, Helton Luiz Aparecido Defino ${ }^{12}$

\begin{abstract}
Objective: To develop a consensus for translation of the most relevant terms used in the study of Adult Spinal Deformity, from their original languages into Brazilian Portuguese. Methods: A panel of 12 experts in spine surgery from the five Brazilian regions was constituted. To obtain the standardization of terminology, the Delphi method with an electronic questionnaire was administered to participants about their opinion on the translation of 13 relevant terms chosen by literature review. Each term was considered standard when there was consensus, that is, concordance higher than $80 \%$ among participants as to the suggestion to be adopted, and then on the acceptance of the term and its abbreviation in Portuguese. Results: Initially there was consensus (over $80 \%$ concordance) on the translation of seven terms in the electronic questionnaire. The other six terms that have not reached consensus were discussed at a meeting among the participants, relying on the opinion of a specialized professional in simultaneous translation of orthopedic terms in Portuguese and other professional majored in Portuguese language. It was decided how these terms should be translated and there was a consensus among all participants regarding their acceptance. Finally, there was consensus among the participants, who agreed with the translation and abbreviation of the 13 propose terms, defining its standardization for Brazilian Portuguese. Conclusion: We present a standard terminology used in the study of Adult Spinal Deformity through consensus among experts, seeking uniformity in the use of these terms in Brazilian Portuguese.
\end{abstract}

Keywords: Scoliosis; Terminology; Translating; Spine; Consensus development conference.

\section{RESUMO}

Objetivo: Estabelecer um consenso para a tradução ao português dos termos mais relevantes utilizados no estudo da deformidade da coluna vertebral do adulto, a partir do original em outras línguas. Métodos: Um painel foi constituído por 12 especialistas em cirurgia da coluna vertebral que atuam nas cinco regiões territoriais do Brasil. Para obtenção da padronização da terminologia, empregou-se o método Delphi, com questionário eletrônico aplicado aos participantes quanto a sua opinião sobre a tradução de treze termos relevantes, escolhidos por revisão da literatura. A tradução de cada termo foi considerada padronizada quando se obteve consenso, isto é concordância superior a 80\% entre os participantes, quanto à sugestão a ser adotada e, em seguida, concordância quanto à aceitação do termo e de sua abreviatura em português. Resultados: Inicialmente, houve consenso (concordância superior a 80\%) quanto à tradução de sete termos apresentados no questionário eletrônico. Os seis demais termos que não atingiram consenso foram discutidos em reunião entre os participantes do estudo, contando com a opinião de uma profissional especializada em tradução simultânea em eventos ortopédicos e de outra, graduada em língua portuguesa. Foi decidida a forma como esses termos deveriam ser traduzidos, sendo que houve consenso entre os participantes em aceitar essa decisão. Por último, houve consenso entre os participantes, que concordaram com a tradução e com a abreviatura dos 13 termos propostos, definindo-se sua padronização para a língua portuguesa brasileira. Conclusões: Apresentamos uma padronização da terminologia utilizada no estudo da deformidade da coluna vertebral do adulto, por meio de consenso entre especialistas, buscando a uniformidade no emprego desses termos no português brasileiro.

Descritores: Escoliose; Terminologia; Tradução; Coluna vertebral; Conferência de consenso.

\section{RESUMEN}

Objetivo: Establecer un consenso para la traducción al portugués de los términos más importantes utilizados en el estudio de la deformidad espinal del adulto, desde el original. Métodos: Se constituyó un panel con 12 expertos en cirugía de la columna vertebral de las cinco regiones territoriales de Brasil. Para la estandarización de la terminología, se utilizó el método Delphi, con cuestionario electrónico administrado a los participantes acerca de su opinión sobre la traducción de 13 términos relevantes, elegidos por revisión de la literatura. La

\footnotetext{
1. Hospital do Servidor Público Estadual (HSPE), São Paulo, SP, Brazil.

2. Hospital Mãe de Deus, Porto Alegre, RS, Brazil.

3. Instituto de Patologia da Coluna (IPC), São Paulo, SP, Brazil.

4. Instituto Nacional de Traumatologia e Ortopedia (INTO), Rio de Janeiro, RJ, Brazil.

5. Hospital Porto Dias, Belém, PA, Brazil.

6. Centro de Reabilitação Dr. Henrique Santillo CRER, Goiânia, GO, Brazil.

7. Instituto Dr. José Frota, Fortaleza, CE, Brazil.

8. Universidade de Caxias do Sul, Caxias do Sul, RS, Brazil.

9. Hospital Geral do Estado, Salvador, BA, Brazil.

10. Instituto de Ortopedia eTraumatologia (IOT), Joinvile, SC, Brazil.

11. Universidade Federal do Mato Grosso do Sul (UFMS), Campo Grande, MS, Brazil.

12. Faculdade de Medicina de Ribeirão Preto da USP, Ribeirão Preto, SP, Brazil.
}

This work is the result of a multicenter study.

Correspondence: Rua Borges Lagoa, 1755, Sala 180, Vila Clementino, São Paulo SP, Brazil. 04038-034. pratalir@gmail.com 
traducción de cada término se consideró estándar cuando hubo consenso, o sea, > 80\% de concordancia entre los participantes en cuanto la sugerencia a ser adoptada y luego la aceptación del término y su abreviatura en portugués. Resultados: Inicialmente, hubo consenso (acuerdo > 80\%) con respecto a la traducción de siete términos. Los otros seis términos que no mostraron consenso, se discutieron en una reunión entre los participantes del estudio, basándose en la opinión de un profesional especializado en traducción simultánea y otro en el idioma portugués. Se decidió como se deben traducir estos términos, y los participantes aceptaron esta decisión. Por último, hubo consenso entre los participantes, que estuvieron de acuerdo con la traducción y la abreviatura de los 13 términos propuestos, definiendo el estándar del portugués brasileño. Conclusiones: Se presenta una terminología estándar utilizada en el estudio de deformidad espinal del adulto por consenso entre los expertos, buscándose la uniformidad del uso de estos términos en el portugués de Brasil.

Descriptores: Escoliosis; Terminología; Traducción; Columna vertebral; Conferencia de consenso.

\section{INTRODUCTION}

Adult Spinal Deformity (ASD) comprises a complex variety of clinical entities and radiographic presentations. ${ }^{1-6}$ Recent studies have documented a high prevalence of over $60 \%$ in individuals older than 60 years of age..$^{7}$ For an understanding of this complex disease, as well as for individual patient assessment and treatment planning, it is important to analyze certain radiographic parameters that have been proven to correlate with patient quality of life..$^{8-10}$ The terminology describing these parameters was originally established in other languages, mainly French and English.

In the study of ASD, various publications have shown that both the type of curve in the sagittal plane and the magnitude of these curves are less important than an overall analysis of the sagittal plane of the spine. ${ }^{8-10}$ Similarly, it has become apparent that the role of the spine alone is insufficient, as it is closely related to, and influenced by the pelvis and the lower limbs. ${ }^{10,11}$ These concepts originated mainly in France, with the pioneering studies of Jean Dubosset and Legaye \& Duval-Beaupere. ${ }^{12-14}$

The alignment and balance of the spine in the sagittal plane are evaluated using the parameter known as "Sagittal Balance", derived from the original French term "Équilibre Sagittal". Even though the parameters defined as "Thoracic Kyphosis" and "Lumbar Lordosis" are probably the most commonly assessed in the study of the sagittal plane of the spine, overall spinal alignment can only be evaluated using the "plumbline" method. In this context, Jackson and McManus ${ }^{15}$ presented the concept of the "Sagittal Vertical Axis", which is defined as the distance of the "plumbline" from the center of C7 to the posterosuperior portion of S1. Another effective method for assessing overall sagittal alignment is the parameter "T1 Spinopelvic Inclination" defined by Duval-Beaupere, ${ }^{13}$ which, being an angle, has the advantage that its measurement does not need to be calibrated. In addition, Lafage and collaborators ${ }^{10}$ showed that this parameter is more closely correlated with quality of life indicators than the "Sagittal Vertical Axis".

Analysis of the pelvic parameters in relation to the sagittal alignment of the spine enables the definition of "Spinopelvic Balance", a term also derived from the original French term "Équilibre Rachis-Pelvis". This analysis involves three angles known as "Pelvic Incidence", "Pelvic Tilt", and "Sacral Slope", ${ }^{14}$ first described in French as "Incidence Pelvienne", "Version Pelvienne", and "Pente Sacrée", ${ }^{13}$ respectively. Various studies have shown that there is close correlation between "Pelvic Incidence" and "Lumbar Lordosis, which can be expressed by the formula $L L=P I+9^{\circ}( \pm 9) \cdot{ }^{11,16}$ This relationship allows the required amount of "Lumbar Lordosis" to be determined from the value of the "Pelvic Incidence". Subsequently, "Pelvic Incidence" was used to describe distinct subtypes of the contour of the sagittal spine. ${ }^{17,18}$ The most recent ASD classification system, known as SRS-Schwab, ${ }^{19}$ considers the type of curve in the coronal or sagittal aspect and presents sagittal aspect modifiers that take three radiographic parameters into account: "Sagittal Vertical Axis", "Pelvic Tilt", and "Pelvic Incidence - Lumbar Lordosis Mismatch".

Recently, a new radiographic parameter, "T1 Pelvic Angle", was introduced. This parameter enables analysis of the interaction between the overall parameter "Sagittal Vertical Axis" and the pelvic parameter "Pelvic Tilt", combining the information obtained for both. Another advantage of this parameter is that, as it is an angle, it requires no calibration for radiographic measurement. It has been shown that this radiographic parameter is clinically correlated with and permits a categorization of deformity comparable to that of the SRS-Schwab classification system.

In Brazil, several articles have been published in Portuguese on the study of ASD using non-standard terms for some of the parameters discussed above. ${ }^{21,22}$ However, to date, no standardization of the terminology of these parameters exists and there is a significant amount of variation in their usage. The objective of this study was to establish a consensus on the translation of the most relevant terms used in the study of adult spinal deformity from their original languages into Brazilian Portuguese.

\section{METHODS}

To achieve a consensus on the standardization of the terminology for the parameters used in ASD, we used the Delphi method, a technique that brings together a panel of subject matter experts from various geographically distinct locations dedicated to solving a specific problem. ${ }^{23,24}$ Approval by the Ethics Committee was not required.

Literature review: To begin the study, a systematic review of the literature was conducted in search of the most relevant terms in the study of ASD, frequently cited in articles published in English, in addition to some original articles presenting the concepts of certain parameters in the language of origin, mainly French.

Participants: Twelve spine surgery experts were invited to participate in the study, including neurosurgeons and orthopedists, from all five regions of the country. These experts were selected for their experience in the treatment and study of ASD, and because they occupied, or had occupied positions of leadership in respected academic institutions, or as members of the Sociedade Brasileira de Coluna [Brazilian Spine Society].

Research: The participants were contacted and informed about the study objective and methods. The participants'opinions about what they considered to be the most suitable translation of the terms into Portuguese were collected via the SurveyMonkey ${ }^{\circledR}$ electronic research service.

Delphi Method $-1^{\text {st }}$ Step: The terms selected from the literature review were presented to the participants, who answered the questionnaire with the form that they considered to be correct in Portuguese. The participants were then asked to add any term in the original language not on the initial list of terms that they considered important. The answers to the questionnaires were submitted anonymously. The Portuguese terms that had agreement among the participants equal to or greater than $80 \%$ were considered to be standardized by consensus.

Delphi Method $-2^{\text {nd }}$ Step: The results from the first step were analyzed for terms that achieved consensus and for the inclusion of terms suggested by the participants that were not on the initial terminology list. The terms that did not achieve consensus were discussed among the participants, in an attempt to reach consensus, and a new questionnaire including only those terms was presented to the participants

Delphi method $-3^{\text {rd }}$ Step: After a consensus was reached for all the terms, a new questionnaire was sent to the participants containing the translated terms in accordance with the previous steps of the study and also the abbreviations of these terms, asking them to agree or disagree with the standardized form. If at least $80 \%$ of the participants agreed, the term would be officially standardized. 


\section{RESULTS}

Participants: Among the spine surgery experts who participated in the study, eleven were orthopedists and one was a neurosurgeon. In terms of their regional distribution, three experts were from the South region, four from the Southeast region, two from the Center-West region, two from the Northeast region, and one from the North region. The average age of the participants was 47.75 years, and the average years of experience in the area was 17.41 .

Research: As a result of the literature review, the questionnaire was sent to the participants to obtain their version in Portuguese of each term considered important to the study of ASD. A total of thirteen terms was selected. (Table 1)

Delphi Method: In the first step of the study, there was consensus, in which the version in Portuguese was the same among $\geq 80 \%$ of the participants (at least ten out of twelve), for seven of the terms, and their translations were accepted. There was no consensus on the other six terms (Table 3). No additional terms were suggested.

We requested the assistance of a professional with experience in simultaneous translation at scientific events in the spine field and a professional with a language degree in Portuguese. These suggestions were presented and discussed at a meeting attended by eight of the twelve participants, in which the translations for the six terms were defined. (Table 4) This information was then presented to the four study participants who were not able to attend the meeting with a new questionnaire asking them whether they agreed or disagreed with the decisions regarding the translation of the six terms. There was consensus ( $\geq 80 \%$ of the participants) on the translation of the terms.

Table 1. Terms used in the study of adult spinal deformity, selected from the literature, to be standardized in Brazilian Portuguese.

\begin{tabular}{|c|c|c|c|c|c|c|}
\hline \multicolumn{7}{|c|}{ 1. Sagittal balance / Équilibre sagittal } \\
\hline \multicolumn{7}{|c|}{ 2. Sagittal alignment } \\
\hline \multicolumn{7}{|c|}{ 3. Spinoplevic balance / Équilibre rachis-pelvis } \\
\hline \multicolumn{7}{|c|}{ 4. Lumbar lordosis } \\
\hline \multicolumn{7}{|c|}{ 5. Thoracic kyphosis } \\
\hline \multicolumn{7}{|c|}{ 6. Plumbline } \\
\hline \multicolumn{7}{|c|}{ 7. Sagittal vertical axis } \\
\hline \multicolumn{7}{|c|}{ 8. T1 Spinopelvic inclination } \\
\hline \multicolumn{7}{|c|}{ 9. Pelvic incidence / Incidence pelvienne } \\
\hline \multicolumn{7}{|c|}{ 10. Pelvic tilt / Version pelvienne } \\
\hline \multicolumn{7}{|c|}{ 11. Sacral slope / Pente sacrée } \\
\hline \multicolumn{7}{|c|}{ 12. Pelvic incidence - Lumbar lordosis mismatch } \\
\hline \multicolumn{7}{|c|}{ 13. T1 Pelvic angle } \\
\hline \multicolumn{7}{|c|}{$\begin{array}{l}\text { Table 2. Questionnaire responses for the seven terms that achieved consen- } \\
\text { sus ( } \geq 80 \%) \text {, with the percentage (\%) each received among the participants. }\end{array}$} \\
\hline $\begin{array}{c}\text { Sagittal } \\
\text { balance/ } \\
\text { Équilibre } \\
\text { sagittal }\end{array}$ & $\begin{array}{l}\text { Sagittal } \\
\text { alignment }\end{array}$ & $\begin{array}{l}\text { Lumbar } \\
\text { lordosis }\end{array}$ & $\begin{array}{l}\text { Thoracic } \\
\text { kyphosis }\end{array}$ & Plumbline & \begin{tabular}{|c|} 
Pelvic \\
incidence/ \\
Incidence \\
pelvienne
\end{tabular} & $\begin{array}{l}\text { Sacral } \\
\text { slope/ } \\
\text { Pente } \\
\text { sacrée }\end{array}$ \\
\hline $\begin{array}{c}\text { Equilíbrio } \\
\text { sagital } \\
(83.3 \%)\end{array}$ & \begin{tabular}{|} 
Alinhamento \\
sagital (100\%)
\end{tabular} & $\begin{array}{c}\text { Lordose } \\
\text { lombar } \\
(100 \%)\end{array}$ & $\begin{array}{c}\text { Cifose } \\
\text { torácica } \\
(91.6 \%)\end{array}$ & $\begin{array}{c}\text { Linha de } \\
\text { prumo } \\
(83.3 \%)\end{array}$ & $\begin{array}{c}\text { Incidência } \\
\text { pélvica } \\
(100 \%)\end{array}$ & $\begin{array}{c}\text { Inclinação } \\
\text { sacral } \\
(83.3 \%)\end{array}$ \\
\hline \multirow[t]{2}{*}{$\begin{array}{c}\text { Balanço } \\
\text { sagital } \\
(16.7 \%)\end{array}$} & & & $\begin{array}{l}\text { Cifose } \\
\text { dorsal } \\
(8.3 \%)\end{array}$ & $\begin{array}{l}\text { Fio de } \\
\text { prumo } \\
(8.3 \%)\end{array}$ & & $\begin{array}{c}\text { Inclinação } \\
\text { do sacro } \\
(8.3 \%)\end{array}$ \\
\hline & & & & $\begin{array}{c}\text { Linha } \\
\text { verticalizada } \\
(8.3 \%)\end{array}$ & & $\begin{array}{l}\text { Sacral } \\
\text { slope } \\
(8.3 \%)\end{array}$ \\
\hline
\end{tabular}

In the final step, the participants responded to a questionnaire indicating whether they agreed or disagreed with the translations of the thirteen terms, as they would be standardized, as well as their abbreviations. A consensus was reached ( $\geq 80 \%$ of the participants) for the translations of all the terms and their abbreviations (Table 5). In this way, the translation into Brazilian Portuguese of terms used in the study of ASD was standardized. (Table 6)

Table 3. Questionnaire responses for the six terms that did not achieve consensus, with the percentage (\%) each received among the participants.

\begin{tabular}{|c|c|c|c|c|c|}
\hline $\begin{array}{c}\text { Spinoplevic } \\
\text { balance / } \\
\text { Équilibre } \\
\text { Rachis-Pelvis }\end{array}$ & $\begin{array}{l}\text { Sagittal } \\
\text { vertical } \\
\text { Axis }\end{array}$ & $\begin{array}{l}\text { T1 Spinopel- } \\
\text { vic inclination }\end{array}$ & $\begin{array}{c}\text { Pelvic tilt/ } \\
\text { Version } \\
\text { pelvienne }\end{array}$ & $\begin{array}{c}\text { Pelvic incidence } \\
\text { - Lumbar lordosis } \\
\text { mismatch }\end{array}$ & $\begin{array}{c}\text { T1 Pelvic } \\
\text { angle }\end{array}$ \\
\hline $\begin{array}{c}\text { Equilíbrio } \\
\text { espinopélvico } \\
(50 \%)\end{array}$ & $\begin{array}{l}\text { Eixo } \\
\text { sagital } \\
\text { vertical } \\
(66.7 \%)\end{array}$ & \begin{tabular}{|} 
Inclinação T1- \\
-Espinopélvico \\
$(16.7 \%)$
\end{tabular} & $\begin{array}{l}\text { Versão } \\
\text { pélvica } \\
(41.7 \%)\end{array}$ & $\begin{array}{c}\text { Diferença entre } \\
\text { incidência pélvica } \\
\text { e lordose lombar } \\
(16.7 \%)\end{array}$ & $\begin{array}{l}\text { Ângulo } \\
\text { T1-pélvico } \\
\text { (16.7\%) }\end{array}$ \\
\hline $\begin{array}{c}\text { Equilíbrio } \\
\text { espinopélvico } \\
\text { (33.3\%) }\end{array}$ & $\begin{array}{l}\text { Eixo } \\
\text { vertical } \\
\text { sagital } \\
(25 \%)\end{array}$ & \begin{tabular}{|c|} 
Inclinação \\
espino- \\
pélvica(16.7\%
\end{tabular} & $\left|\begin{array}{c}\text { Inclinação } \\
\text { pélvica } \\
(16.7 \%)\end{array}\right|$ & $\begin{array}{c}\text { Discrepância incidên } \\
\text { cia pélvica - Lordose } \\
\text { lombar (16.7\%) }\end{array}$ & $\begin{array}{c}\text { Ângulo } \\
\text { pélvico-T1 } \\
(16.7 \%)\end{array}$ \\
\hline $\begin{array}{c}\text { Balanço } \\
\text { espinopélvico } \\
\text { (8.3\%) }\end{array}$ & $\begin{array}{c}\text { Axial verti- } \\
\text { cal sagital } \\
(8.3 \%)\end{array}$ & $\begin{array}{c}\text { Inclinação T1- } \\
\text {-espinopélvica } \\
\text { (8.3\%) }\end{array}$ & $\begin{array}{c}\text { Pelvic tilt } \\
(8.3 \%)\end{array}$ & $\begin{array}{c}\text { Diferença incidência } \\
\text { pélvica - lordose } \\
\text { lombar }(8.3 \%)\end{array}$ & $\begin{array}{c}\text { Ângulo T1 } \\
\text { Pélvico } \\
(8.3 \%)\end{array}$ \\
\hline \multirow[t]{7}{*}{$\begin{array}{c}\text { Balanço } \\
\text { espinopélvico } \\
(8.3 \%)\end{array}$} & & \begin{tabular}{|c|} 
Inclinação T1- \\
-espinopélvica \\
(8.3\%)
\end{tabular} & $\begin{array}{c}\text { Balanço } \\
\text { pélvico } \\
(8.3 \%)\end{array}$ & $\begin{array}{c}\text { Dissociação } \\
\text { incidência pélvica - } \\
\text { Lordose (8.3\%) }\end{array}$ & $\begin{array}{c}\text { Ângulo } \\
\text { pélvico T1 } \\
(8.3 \%)\end{array}$ \\
\hline & & \begin{tabular}{|c|} 
Inclinação \\
espinopélvico \\
(8.3\%)
\end{tabular} & $\begin{array}{l}\text { Ante- } \\
\text { versão } \\
\text { pélvica } \\
(8.3 \%)\end{array}$ & $\begin{array}{c}\text { Divergência entre } \\
\text { a incidência pélvica } \\
\text { e Lordose lombar } \\
\text { (8.3\%) }\end{array}$ & $\begin{array}{c}\text { T1 Ângulo } \\
\text { pélvico } \\
\text { (8.3\%) }\end{array}$ \\
\hline & & $\begin{array}{c}\text { Inclinação } \\
\text { espinopélvica } \\
\text { de T1 (8.3\%) }\end{array}$ & \begin{tabular}{|c|} 
Inclinação \\
pélvica/ \\
versão \\
pelve \\
(8.3\%)
\end{tabular} & $\begin{array}{c}\text { Discordância } \\
\text { lordose lombar - } \\
\text { Incidência pélvica } \\
(8.3 \%)\end{array}$ & $\begin{array}{l}\text { Ângulo T1- } \\
\text {-Inclinação } \\
\text { pélvica } \\
(8.3 \%)\end{array}$ \\
\hline & & \begin{tabular}{|c|} 
Inclinação \\
espinopélvica \\
de T1 (8.3\%):
\end{tabular} & $\begin{array}{c}\text { Versão ou } \\
\text { inclinação } \\
\text { pélvica } \\
(8.3 \%)\end{array}$ & $\begin{array}{c}\text { Desadequação/ } \\
\text { discrepância/ } \\
\text { diferença entre } \\
\text { incidência pélvica - } \\
\text { Lordose } \\
\text { lombar(8.3\%) }\end{array}$ & $\begin{array}{c}\text { Ângulo } \\
\text { pelve-T1 } \\
(8.3 \%)\end{array}$ \\
\hline & & \begin{tabular}{|c|} 
Inclinação \\
espinopélvica \\
T1 (8.3\%)
\end{tabular} & & $\begin{array}{c}\text { Relação entre } \\
\text { incidência-Pélvica } \\
\text { e lordose lombar } \\
\text { (8.3\%) }\end{array}$ & $\begin{array}{c}\text { Angulação } \\
\text { pélvica } \\
(8.3 \%)\end{array}$ \\
\hline & & $\begin{array}{c}\text { T1 Inclinação } \\
\text { espinopélvica } \\
\text { (8.3\%) }\end{array}$ & & $\begin{array}{l}\text { Lordose lombar } \\
\text { (8.3\%) }\end{array}$ & $\begin{array}{c}\text { Ângulo } \\
\text { pélvico de } \\
\text { T1 (8.3\%) }\end{array}$ \\
\hline & & \begin{tabular}{|c|} 
Inclinação \\
espinopélvica- \\
-T1 (8.3\%)
\end{tabular} & & /III (8.3\%) & $\begin{array}{l}\text { Ângulo } \\
\text { T1-pelve } \\
(8.3 \%)\end{array}$ \\
\hline
\end{tabular}


Table 4. Decision for Portuguese terminology for the terms that did not obtain consensus, following the meeting of study participants.

\begin{tabular}{c|c}
\hline Original term & Term in Portuguese \\
\hline $\begin{array}{c}\text { Spinoplevic balance / } \\
\text { Équilibre rachis-pelvis }\end{array}$ & Equilíbrio espinopélvico \\
\hline Sagittal vertical axis & Eixo vertical sagital \\
\hline T1 Spinopelvic inclination & Inclinação T1 espinopélvica \\
\hline Pelvic tilt / Version pelvienne & Versão pélvica \\
\hline $\begin{array}{c}\text { Pelvic incidence - Lumbar } \\
\text { lordosis mismatch }\end{array}$ & Discrepância entre incidência pélvica e \\
\hline T1 Pelvic angle & Ândose lombar \\
\hline
\end{tabular}

Table 5. Final step - Evaluation of the rates of concordance and discordance among the participants for the terms to be standardized in Portuguese.

\begin{tabular}{c|c|c}
\hline Term & Concordance & Discordance \\
\hline Equilíbrio sagital (ES) & $100 \%$ & 0 \\
\hline Alinhamento sagital (AS) & $100 \%$ & 0 \\
\hline Equilíbrio espinopélvico (EEP) & $100 \%$ & 0 \\
\hline Lordose lombar (LL) & $100 \%$ & 0 \\
\hline Cifose torácica (CT) & $100 \%$ & 0 \\
\hline Linha de prumo (LP) & $100 \%$ & 0 \\
\hline Eixo vertical sagital (EVS) & $100 \%$ & 0 \\
\hline Inclinação T1 espinopélvica (ITEP) & $100 \%$ & 0 \\
\hline Incidência pélvica (IP) & $100 \%$ & 0 \\
\hline Versão pélvica (VP) & $91.7 \%$ & $8.3 \%$ \\
\hline Inclinação sacral (IS) & $100 \%$ & 0 \\
\hline Discrepância entre incidência & $100 \%$ & 0 \\
pélvica e lordose lombar (IP-LL) & & 0 \\
\hline Ângulo T1 pélvico (ATP) & $100 \%$ &
\end{tabular}

Table 6. Standardization of the terminology and respective abbreviations used for the study of adult spinal deformity (ASD) in Portuguese.

\begin{tabular}{c|c}
\hline Original term & $\begin{array}{c}\text { Standardization to Portuguese } \\
\text { and Abbreviation }\end{array}$ \\
\hline Sagittal balance / Équilibre sagittal & Equilíbrio sagital (ES) \\
\hline Sagittal alignment & Alinhamento sagital (AS) \\
\hline $\begin{array}{c}\text { Spinoplevic balance / } \\
\text { Équilibre rachis-pelvis }\end{array}$ & Equilíbrio espinopélvico (EEP) \\
\hline Lumbar lordosis & Lordose lombar (LI) \\
\hline Thoracic kyphosis & Cifose torácica (CT) \\
\hline Plumbline & Linha de prumo (LP) \\
\hline Sagittal vertical axis & Eixo vertical sagital (EVS) \\
\hline T1 Spinopelvic inclination & Inclinação T1 espinopélvica (ITEP) \\
\hline Pelvic incidence / Incidence & Incidência pélvica (IP) \\
\hline pelvienne & Versão pélvica (VP) \\
\hline Pelvic tilt / Version pelvienne & Inclinação sacral (IS) \\
\hline Sacral slope / Pente sacrée & lordose lombar (IP-LL) \\
\hline Pelvic incidence - & Ângulo T1 pélvico (ATP) \\
\hline Lumbar lordosis mismatch &
\end{tabular}

\section{DISCUSSION}

An understanding of the different radiographic parameters, most of them evaluated in the sagittal plane, is essential for the identification, classification, and treatment planning of ASD. These parameters have been sequentially described in numerous publications, and their importance and clinical relevance have been proven, but the terminology used is always in French or English. In Brazil, there is no uniform usage of these parameters because few articles have been published using the terminology in Portuguese. 21,22 Therefore, we believe there is a need to standardize the Brazilian Portuguese translations of the important terms used in the study of adult spinal deformity.

A process of reaching a consensus among experts in the area of spine deformity was chosen to accomplish this standardization. The Delphi method was used with a panel of specialists experienced in the treatment of the pathology. ${ }^{23,24}$ This method is often used to obtain a consensus in the literature ${ }^{25,26}$ that leverages the standardized judgment of these specialists, who represent the professionals who will be using the translated terms. ${ }^{24,27}$

It was no surprise that a consensus was reached for the translations of some terms, such as "equilíbrio sagital","alinhamento sagital", "lordose lombar", "cifose torácica", "linha de prumo", "incidência pélvica", and "inclinação sacral" in the first step. The terms "alinhamento sagital", "lordose lombar", and "incidência pélvica" achieved $100 \%$ concordance among the participants in the first pass of the questionnaire. Although there was consensus (concordance $\geq 80 \%$ ) among the participants, the terms "equilíbrio sagital", "cifose torácica", "linha de prumo", and "inclinação sacral" had at least one suggested translation other than the one that was standardized.

The six terms that did not obtain consensus were analyzed and discussed in a meeting attended by eight of the twelve study participants, where the opinions of a professional with experience in translating orthopedic terms from English to Portuguese, and a professional with a language degree in Portuguese, were considered. Whether or not a hyphen was required between the terms "espino" and "pélvico" was discussed, and given that it is not mandatory according to rules of grammar, the group decided to use "espinopélvico" without the hyphen. There was disagreement over the standardization of the term "Sagittal Vertical Axis" regarding the order of the words in Portuguese. The group decided to keep the word in the middle, while inverting the beginning and ending words, resulting in "eixo vertical sagital".

There was also a lot of discussion about the term "pelvic tilt/ version pelvienne". This parameter was first defined in French, ${ }^{13}$ also a Romance language, as "version", in addition to the fact that in Portuguese, a high value is associated with "retroversão" of the pelvis and a low value with "anteversão" of the pelvis. So the term "versão pélvica" was established for use in Brazilian Portuguese.

The disagreement over the term "pelvic incidence - lumbar lordosis mismatch" revolved mostly around the word "mismatch". Considering the concept of the term, which corresponds to the value of the lumbar lordosis being influenced by the value of the pelvic incidence, with functional changes being apparent when the lordosis is lower than expected in relation to the pelvic incidence, ${ }^{11}$ the group decided to adopt the term "discrepância entre incidência pélvica e lordose lombar".

The parameters "T1 Spinopelvic Inclination" and "T1 Pelvic Angle" also created significant divergence. During the meeting, the participants decided to start the term with the parameter measured, i. e. "ângulo" or "inclinação", followed by "T1", and then by the term relating to the pelvis, in the proximal to distal direction. Thus, we have "inclinação T1 espinopélvica" and "ângulo T1 pélvico".

Next, the thirteen terms were presented to the twelve participants to see whether there was a consensus with the concordance $(\geq$ $80 \%$ of the participants), which would indicate standardization of the terminology and the abbreviations to be used. All the terms and abbreviations achieved $100 \%$ agreement, with the exception of "versão 
pélvica" with one participant (8.3\%) in disagreement, though the term also achieved consensus.

Thus, the study defined the standardization of the most important Brazilian Portuguese terminology for the study of ASD through the consensus of experiences specialists. We believe that with the extensive dissemination of the results of the study, this process will strengthen the uniform usage of the terminology as established in Brazil, both in future publications and in oral presentations

\section{CONCLUSIONS}

We present a standardization of the terminology used in the study of adult spinal deformity through consensus among specialists, seeking uniformity in the usage of these terms in Brazilian Portuguese.

\section{ACKNOWLEDGEMENTS}

Tone Isey Sguizzardi and Silvana dos Reis Fernandes Lobato

All authors declare no potential conflict of interest concerning this article.

\section{REFERENCES}

1. Aebi M The adult scoliosis. Eur Spine J. 2005·14(10):925-48.

2. Bess S, Boachie-Adjei O, Burton D, Cunningham M, Shaffrey C, Shelokov A, et al. Pain and disability determine treatment modality for older patients with adult scoliosis, while deformity guides treatment for younger patients. Spine (Phila Pa 1976). 2009:34(20):2186-90.

3. Smith JS, Fu KM, Urban P, Shaffrey Cl. Neurological symptoms and deficits in adults with scoliosis who present to a surgical clinic: incidence and association with the choice of operative versus nonoperative management. J Neurosurg Spine. 2008:9(4):326-31.

4. Smith JS, Shaffrey $\mathrm{Cl}$, Berven S, Glassman S, Hamill C, Horton W, et al. Operative versus nonoperative treatment of leg pain in adults with scoliosis: a retrospective review of a prospective multicenter database with two-year follow-up. Spine (Phila Pa 1976). 2009:34(16):1693-8.

5. Smith JS, Shaffrey Cl, Berven S, Glassman S, Hamill C, Horton W, et al. Improvement of back pain with operative and nonoperative treatment in adults with scoliosis. Neurosurgery. 2009;65(1):86-93.

6. Smith JS, Shaffrey Cl, Glassman SD, Berven SH, Schwab FJ, Hamill CL, et al. Risk-benefit assessment of surgery for adult scoliosis: an analysis based on patient age. Spine (Phila Pa 1976). 2011;36(10):817-24.

7. Schwab F, Dubey A, Gamez L, El Fegoun AB, Hwang K, Pagala M, et al. Adult scoliosis: prevalence, SF-36, and nutritional parameters in an elderly volunteer population. Spine (Phila Pa 1976). 2005;30(9):1082-5.

8. Glassman SD, Berven S, Bridwell K, Horton W, Dimar JR. Correlation of radiographic parameters and clinical symptoms in adult scoliosis. Spine (Phila Pa 1976). 2005;30(6):682-8.

9. Glassman SD, Bridwell K, Dimar JR, Horton W, Berven S, Schwab F. The impact of positive sagittal balance in adult spinal deformity. Spine (Phila Pa 1976). 2005:30(18):2024-9.

10. Lafage V, Schwab F, Patel A, Hawkinson N, Farcy JP. Pelvic tilt and truncal inclination: two key radiographic parameters in the setting of adults with spinal deformity. Spine (Phila Pa 1976). 2009;34(17):E599-606.

11. Schwab F, Lafage V, Patel A, Farcy JP. Sagittal plane considerations and the pelvis in the adult patient. Spine (Phila Pa 1976). 2009;34(17):1828-33.

12. Dubousset J. Importance de la verte'bre pelvienne dans l'e 'quilibre rachidien. Application a' la chirurgie de la colonne verte brale chez l'enfant et l'adolescent. In: Villeneuve P, editor. Pied équilibre et Rachis. Paris, France: Frison-Roche: 1998. p.141-9.

13. Legaye J. Hecquet J, Marty C, Duval-Beaupere G. Equilibre Sagitall du rachis Relations entre bassin et courbures rachidiennes sagittales en position debout. Rachis 1993:5(3):215-26.

14. Legaye J, Duval-Beaupère G, Hecquet J, Marty C. Pelvic incidence: a fundamental pelvic parameter for three-dimensional regulation of spinal sagittal curves. Eur Spine J. 1998;7(2):99-103.
15. Jackson RP, McManus AC. Radiographic analysis of sagittal plane alignment and balance in standing volunteers and patients with low back pain matched for age, sex, and size. A prospective controlled clinical study. Spine (Phila Pa 1976). 1994;19(14):1611-8.

16. Boulay C, Tardieu C, Hecquet J, Benaim C, Mouilleseaux B, Marty C, et al. Sagittal alignment of spine and pelvis regulated by pelvic incidence: standard values and prediction of lordosis. Eur Spine J. 2006;15(4):415-22.

17. Roussouly P Berthonnaud E, Dimnet J. Geometrical and mechanical analysis of lumbar lordosis in an asymptomatic population: proposed classification]. Rev Chir Orthop Reparatrice Appar Mot. 2003;89(7):632-9.

18. Roussouly P, Gollogly S, Berthonnaud E, Dimnet J. Classification of the normal variation in the sagittal alignment of the human lumbar spine and pelvis in the standing position. Spine (Phila Pa 1976). 2005;30(3):346-53.

19. Schwab F, Ungar B, Blondel B, Buchowski J, Coe J, Deinlein D, et al. Scoliosis Research Society-Schwab adult spinal deformity classification: a validation study. Spine (Phila Pa 1976). 2012;37(12):1077-82.

20. Ryan DJ, Protopsaltis TS, Ames CP, Hostin R, Klineberg E, Mundis GM, et al. T1 pelvic angle (TPA) effectively evaluates sagittal deformity and assesses radiographical surgical outcomes longitudinally. Spine (Phila Pa 1976). 2014;39(15):1203-10.

21. Hennemann SA, Antoneli PHL, De Oliveira GC. Incidência pélvica: um parâmetro fundamental para a definição do equilíbrio sagittal da coluna vertebral. Coluna/Columna. 2012;11(3):237-9

22. Pratali RR, Luz CO, Barsotti CEG, Santos FPE, De Oliveira CEA. Análise do parâmetros do equilíbrio sagital e espino-pélvico em uma amostra populacional brasileira. Coluna/ Columna. 2014;13(2):108-11.

23. Hsu CS, Sandford BA. The Delphi technique: making sense of consensus. Pract Assess Res Eval. 2007;12(10):1-8

24. Linstone FT. The Delphi method: techniques and applications. London: Addison-Wesley; 1975

25. Fisher CG, DiPaola CP, Ryken TC, Bilsky MH, Shaffrey Cl, Berven SH, et al. A novel classification system for spinal instability in neoplastic disease: an evidence-based approach and expert consensus from the Spine Oncology Study Group. Spine (Phila Pa 1976). 2010;35(22):E1221-9.

26. Vitale MG, Riedel MD, Glotzbecker MP, Matsumoto H, Roye DP, Akbarnia BA, et al. Building consensus: development of a Best Practice Guideline (BPG) for surgical site infection (SSI) prevention in high-risk pediatric spine surgery. J Pediatr Orthop. 2013;33(5):471-8.

27. Horton JN. Nominal group technique. A method of decision-making by committee. Anaesthesia. 1980;35(8):811-4. 